\title{
Teaching How to Teach: Microteaching (A Way to Build up Teaching Skills)
}

\author{
Reddy KR \\ Professor of Microbiology \\ Medical Education Department \\ Gandaki Medical College \& Teaching Hospital, Pokhara, Nepal
}

\section{Keywords}

Microteaching, Pedagogi skills,

Teacher training technique.

\section{Corresponding author}

Dr. K. Rajeshwar Reddy

Professor \& HOD of Microbiology Gandaki

Medical College \& Teaching Hospital,

Pokhara, Nepal

Email: reddysir4861@gmail.com

\begin{abstract}
Microteaching is one of the most recent innovations in teacher training program which is used as a professional developmental tool in preservice or in-service teacher training programs. Microteaching helps teachers to better understand the processes of teaching and learning and provides the opportunity to learn teaching skills, to study their own teaching, and to study the teaching of others.

Microteaching is an organized, scaled-down teacher training program where a trainee teacher plans a short lesson, teaches it to a reduced group of students (Three to ten) in a 5 to 20 minute lesson, and then reflects on their teaching afterwards. The lesson is video recorded for either individual or peer review. The trainee teacher's micro-lesson is reviewed, discussed, analyzed, and evaluated to give a feedback. Based on this feedback, the trainee teacher re-teaches the micro-lesson, incorporating those points raised during the discussion and analysis.

The main objective of this article is to address and emphasize that microteaching has the potential to improve the teachers' pedagogic skills, competencies, self-confidence, beliefs, and attitudes with minimum available facilities and to provide students with valuable teaching experiences and make them aware of the benefits and relationships between theory and practice.
\end{abstract}

\section{INTRODUCTION}

For the recruitment of medical teachers, no special prior training in pedagogic techniques is considered necessary. Therefore, the training of in-service medical teachers in specific teaching skills is a major challenge in medical education programs. The pedagogic skills required for medical teachers can be imparted through more structured faculty training programs ${ }^{1}$.

Microteaching is a teacher training technique for learning teaching skills. It employs real teaching situation for developing pedagogic skills and helps to get deeper knowledge regarding the art of teaching ${ }^{2,3}$. Microteaching provides medical teachers an opportunity to build their confidence and improve both content and methods of teaching and develop specific teaching skills through a "teach, critique, re-teach" model ${ }^{4}$. It is a new innovative program for medical teachers, which enhances their classroom attitude and behavior.

Fig 1: Microteaching

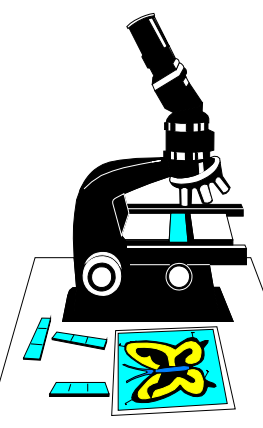




\section{ORIGIN AND DEVELOPMENT OF MICROTEACHING}

Microteaching was first used in medicine at Stanford University in 1960s to promote the quality of students ${ }^{9}$ and then it was applied for teacher training ${ }^{10}$.

The idea of microteaching as teacher training technique originated for the first time at Stanford University (Teacher education program) in USA in 1963 by Dr Dwight W. Allen ${ }^{5}$ and his colleagues. It was first applied to teaching science, but later it was introduced to language teaching. The theoretical basis for this microteaching was initially related to the psychological theory of behaviorism ${ }^{6}$ (Bandura's social learning theory).

Microteaching has become an established teacher training education procedure to raise the level of the teachers' competencies in many colleges and Universities.

\section{DEFINITIONS OF MICROTEACHING}

Microteaching is a concentrated, focused form of peer feedback and discussion that can improve teaching strategies. Microteaching is a system of controlled practice that makes it possible to focus on specific teaching behaviors and to practice teaching under controlled conditions. Competence in one skill is developed before proceeding to another skill. Microteaching has been defined in a number of ways.

Allen DW (1966): Microteaching is a scaled-down teaching encounter in class size and time ${ }^{7}$.

Allen DW and Eve AW (1968): Microteaching is defined as a system of controlled practice that makes it possible to concentrate on specified teaching behavior and to practices teaching under controlled conditions ${ }^{5}$.

Bush RN (1968): Microteaching is a teacher education technique which allows teachers to apply clearly defined teaching skills to carefully prepared lessons in a planned series of five to 10 minutes encounter with a small group of real students, often with an opportunity to observe the result on video ${ }^{8}$

Singh LC (1977): Microteaching is a scaled down teaching encounter in which a teacher teaches a small unit to a group of five pupils for a small period of five to 20 minutes. Such a situation offers a helpful setting for an experienced or inexperienced teacher to acquire new teaching skills and to refine old ones ${ }^{2}$.
Clift JC et al (1976): Microteaching is a teacher training program which reduces the teaching situation to a simpler and more controlled encounter achieved by limiting the practice teaching to a specific skill and reducing time and class size ${ }^{9}$.

Encyclopedia of Education (Ed. Deighton, LC: 1971): Microteaching is a real, constructed, scaled down teaching encounter which is used for teacher training, curriculum development, and research ${ }^{10}$.

\section{OBJECTIVES OF MICROTEACHING}

The main objectives of microteaching $\operatorname{are}^{12}$ :

1. It enables trainee teachers to learn and assimilate new teaching skills under controlled conditions

2. It enables trainee teachers to master a number of teaching skills

3. The trainee teachers gains confidence in teaching, understand the concept and principles underlying microteaching.

4. Also the student can analyze the complex process of teaching into essential microteaching skills and comprehend the procedure of microteaching for developing teaching skills

\section{CONCEPT OF MICROTEACHING}

Microteaching is a relatively a new innovation in the field of teacher education; a highly individualized training device to prepare effective teachers. Microteaching is a real teaching but focuses on developing teaching skills ${ }^{4}$.

Microteaching is so called since it gives trainee teachers an opportunity to safely put themselves "under the microscope" of a small group audience, so that all faults in teaching are observed to get a constructive feed-back and also to observe and comment on others performance.

In microteaching, the trainee teacher is engaged in a scaled-down teaching situation.

i) It is scaled down in terms of class size, since the trainee teacher is teaching a small group of five to 10 pupils. 
Fig 2: Microteaching gives trainee teachers an opportunity to put themselves "under the microscope" of a small group audience
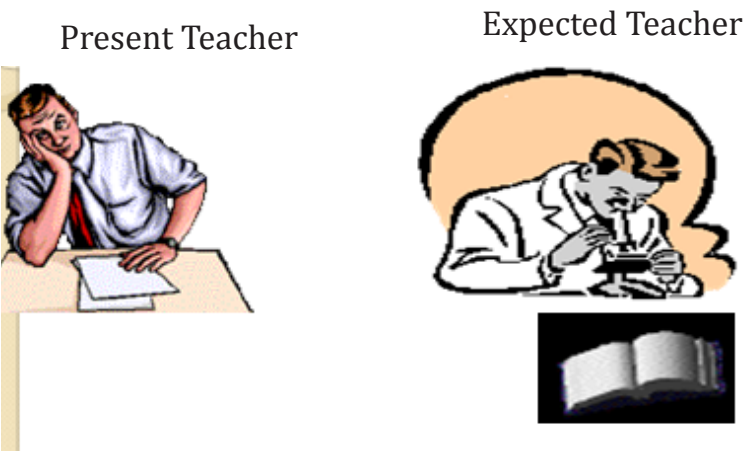

ii) The lesson is scaled down in length of class-time and is reduced to five to 10 minutes. Thus, microteaching lessens the complexities of normal class-room teaching. Class size, scope of content, and time are all reduced.

iii) It is also scaled down in terms of teaching tasks. Only one teaching skill or task is taken up at a time, and practiced through a scaled down encounter and then take others in a similar way. These tasks may include the practicing and mastering of a specific teaching skill such as lecturing or teaching explanation, questioning or leading a discussion; mastering of specific teaching strategies; flexibility, instructional decision making, alternative uses of specific curricula, instructional materials and class room management. Thus, microteaching focuses on training for the accomplishment of specific tasks.

Video recording of the teaching provides adequate feedback for trainee teacher's performance. The trainee teacher immediately views his/her lesson, evaluates it, amends his approach, re-teaches the lesson to another group of pupils, reviews and evaluates. Thus microteaching provides skilled supervision with an opportunity to get a constructive feedback. The class room teaching is like learning to swim at the deeper end of the swimming pool, microteaching is an opportunity to practice at the shallower and less risky side ${ }^{11}$.

Microteaching allows for the increased control of practice. In the practice setting of microteaching, the rituals of time, students, methods of feed-back and supervision, and many other factors can be manipulated. As a result, a high degree of control can be built into the training program. Microteaching greatly expands the normal knowledge of results or feedback dimensions in teaching.

\section{CORE SKILLS APPLICABLE IN CLINICAL TEACHING}

The teaching activity as a whole is divided into its individual component skills ${ }^{4,11,13,14}$.

1. Lesson planning with clear-cut objectives and an appropriate planned sequence. The content should be concise, appropriate, relevant, and could cover the specified duration.

2. Introduction skill (Set induction) - The process of gaining pupil's attention at the beginning of the class by establishing rapport with pupils, promoting their attentions, exposing them to essential contents, and linking their previous knowledge with the topic.

3. Presentation and explanation skills - Teacher enthusiasm, explanation, narration, giving appropriate illustrations and examples, planned repetition, and encouraging group discussion wherever necessary. The trainee teacher should be able to rightly explain the concept by simple, relevant, and interesting examples to increase pupils' understanding.

4. Skill of stimulus variation - Securing and sustaining the attention of the pupil is imperative for a good teacher. The effective components of the skill are

- Gestures (Hand, facial, body)

- Change in the speech pattern

- Voice variation and modulation (Pitch, volume,

- speed)

- Change in the interaction pattern

- Focusing

- Pausing movement

- Emphasis on significant points

5. Proper use of audio-visual aids - The increased awareness of the audiovisual aids and other equipment is important for this skill. Neatness, readability, adequate spacing, distinct size, proper spacing between words and lines, and use of relevant words or phrases are the key components for this skill. 


\section{Skill of black-board writing}

Table 1: The components of the skill of black-board writing

- $\quad$ Legibility (Easy to read)

- $\quad$ Size and alignment (In a straight line)

- Highlighting main points

- Utilization of the space

- Black-board summary

- Correctness

- Position of the teacher

- Contact with the pupils

7. Reinforcement - Recognizing pupil's difficulties, listening, encouraging pupil participation and response. The use of positive verbal and non-verbal cues would be the key components for this skill.

8. Skill of probing questions - Probing questions are those which help the pupils to think in depth about the various aspects of the problem enabling pupils to understand the subject deeply. It is important to allow and encourage the fellow trainee teachers to ask structured questions and clarify doubts. Redirection, refocusing, and increasing critical awareness are important components of this skill.

\section{Silence and nonverbal cues (Body language)}

10. Classroom management - Providing proper instructions, restricting inappropriate behavior, and calling the pupils by name are essentials of this skill.

11. Skill of achieving closure - Method of concluding a teaching session so as to bring out the relevance of what has been learnt, its connection with past learning and its application to future learning. Questions and statements by the teacher by consolidation of the major points covered during the lesson and ability for applying the knowledge gained by pupils during the lesson to new situations. Closure should be timely! Prepare to start and end in time.

\section{PROCEDURE OF MICROTEACHING (MICROTEACHING CYCLE)}

Microteaching is a system of controlled practice that makes it possible to focus on specific teaching behaviors and to practice teaching under controlled conditions. Competence in one skill is developed before proceeding to another skill $4,11,13,15-17$

1. Defining the skill: A particular skill to be practiced is defined and explained to trainee teachers in terms of the purpose, teaching behaviors to provide the knowledge and awareness of the component teaching skills with examples.

2. Demonstrating the skills: The specific skill in microteaching is demonstrated by the experts/ supervisor in simulated conditions or through video to the trainee teacher.

3. Planning the lesson: The trainee teacher selects a topic and plans a short lesson (Micro-lesson) for five to 10 minutes with the help of his/her supervisor, on the basis of demonstrated skill for his/her practice. The lesson planning should be in a logical sequence where maximum application of the components of a skill is possible.

4. Teaching the lesson: The trainee teacher teaches the lesson to a micro-class (A small group of pupils, five to 10) and uses the components of skill as per the planning of the lesson. If the situation is different and not as visualized in the planning of the lesson, the trainee teacher should modify his/her behavior as per the demand of the situation in the class. The trainee teacher should have the courage and confidence to handle the situation arising in the class effectively.

5. The lesson is observed by the supervisor or peers or video recorded or televised at close circuit television (CCTV).

6. Feedback: This term refers to giving information to the trainee teacher about his performance (Points of strength as well as weakness) so that trainee teacher can improve his/her performance in the desired direction. The feedback should be constructive and based on observation. Commenting on observable behavior also leads to suggestions for improvement. Thus the teaching is followed by discussion to provide the feed-back to the trainee on the basis of observation of the lesson. The teaching is evaluated by students, peers and the supervisor. Colleagues and post-graduate students can act as peer evaluators. The supervisor reinforces the instances of effective use of the skill and draws attention of the teacher trainee to the points where he/she could not do well. 
The trainee teacher can observe his/her teaching activities on video or $\mathrm{CCTV}^{8}$. The awareness of his/her own teaching performance provides the reinforcement of the trainee teacher.

7. Re-planning: In the light of the discussion, suggestions and feedback given by the supervisor, the trainee teacher re-plans the lesson incorporating the points of strength in order to practice the small skill effectively in the second trial for improvement.

8.. Re-teaching: The revised lesson is re-taught to another small group of pupils of same class for the same class duration to practice the small skill. This involves teaching to the same group of pupils if the topic is changed or to a different group of pupils if the topic is the same. This is done to eliminate boredom or monotony of the pupil. The trainee teacher teaches the class with renewed courage and confidence to perform better than the previous attempt.

9. Re-feedback: The supervisor observes the re-teach lesson and gives re-feed back to the trainee teacher with convincing arguments and reasons. Thus the reteaching is again followed by discussion, suggestions and encouraging the teaching performance by the re-feedback provided to the trainee teacher. This is the most important component of microteaching for modification of behavior of trainee teachers in the desired direction in each and every skill practice.

10. Repeating the cycle: The "teach-re-teach" cycle may be repeated several times till desired level of skill or adequate mastery is achieved. Such repeated cycles of teaching, feedback and re-teaching help the teacher to improve his teaching skills one at a time.

Fig 3: Microteaching cycle (The cycle continues up to the extend when a trainee will be able to master a specific skill)

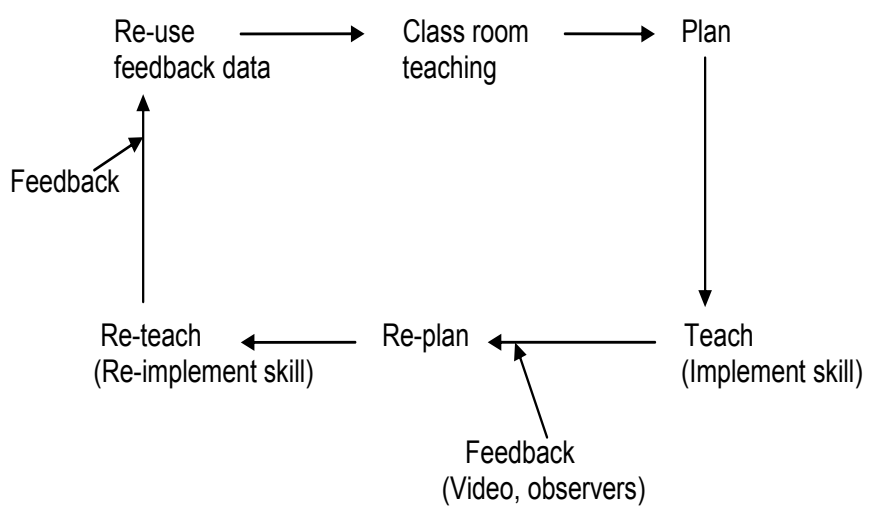

TIME DURATION FOR THE MICROTEACHING

\begin{tabular}{ll}
\hline \multicolumn{3}{c}{ Planning of micro-lesson may take 2 hours } \\
1. Time duration \\
Teach & $5-6$ minutes \\
Feedback session & $5-6$ minutes \\
Re-plan & $10-12$ minutes \\
Re-teach another group & $5-6$ minutes \\
Re-feedback & $5-6$ minutes \\
Total & $30-36$ minutes approximately \\
2. Number of trainee & 10 \\
3. $\quad$ teachers in a group & Supervisor(s) \\
4. & Feedback by supervisor(s)/ peers \\
\hline
\end{tabular}

\section{PHASES OF MICROTEACHING}

Microteaching procedure has various phases of acquiring skills $^{4,11,13,17}$.

1. Knowledge acquisition phase (Pre-active phase): It is the preparatory pre-active phase in which the teacher gets trained on the skills and components of teaching through lectures, discussion illustration and demonstration of skills by experts. The trainee teacher gets theoretical as well as the practical knowledge of the skill.

2. Skill acquisition phase (Inter-action phase): In this inter-active skill acquisition phase the trainee teacher plans a micro-lesson for practicing the demonstrated skills and carries out the microteaching cycle and evaluation of the practiced skill (Feedback), then replan, re-teach and re-feedback till the desired level of

3. skill achieved.

4. Transfer phase (Post-active phase): Here, the trainee teacher uses the mastered skill in the real class room teaching and tries to integrate all the different skills.

\section{ADVANTAGES OF MICROTEACHING}

A microteaching session is much more comfortable than real class room situations, because it eliminates pressure resulting from the length of the lecture, the scope and content of the matter to be conveyed, and the need to face large numbers of students, some of whom may be 
inattentive or hostile. Another advantage of microteaching is that it provides skilled supervisors who can give support, lead the session in a proper direction ${ }^{4,11,18}$.

- It helps to develop, sharpen and master specific teaching skills

- It employs real teaching situation for developing teaching skills

- It helps to accomplish specific teaching competencies

- It is more effective in understanding and modifying teacher behaviors important in class room teaching

- It increases the confidence of trainee teacher

- It is a vehicle of continuous training applicable at all stages not only to teachers at the beginning of their career but also for more senior teachers

- It enables projection of model instructional skills

- It provides expert supervision and a constructive feedback

- It provides for repeated practice without adverse consequences to the trainee teacher or his/her students

- It reduces the complexity of teaching process as it is a scaled down teaching

- It helps to get deeper knowledge regarding the art of teaching

- It caters for individual differences of prospective teachers in their training

- Duration of teaching as well as number of students are less

- Content is divided into smaller units

- There is facility of re-planning, re-teaching and reevaluation

- It puts the teacher under the microscope, and all the faults of the teacher are observed

- The problem of discipline can also be controlled

Table 2: Changes in teacher role

\begin{tabular}{|c|c|c|}
\hline & A shift from & A shift to \\
\hline 1 & $\begin{array}{l}\text { Knowledge transmitter, pri- } \\
\text { mary source of information, } \\
\text { content expert, and source of } \\
\text { all answers }\end{array}$ & $\begin{array}{l}\text { Learning facilitator, Collaborator, } \\
\text { Coach, Mentor, Knowledge } \\
\text { navigator, and co-learner }\end{array}$ \\
\hline 2 & $\begin{array}{l}\text { Teacher controls and directs all } \\
\text { aspects of learning }\end{array}$ & $\begin{array}{l}\text { Teacher gives students more } \\
\text { options and responsibilities for } \\
\text { their own learning }\end{array}$ \\
\hline
\end{tabular}

Table 3: Changes in student role

\begin{tabular}{lll}
\hline \multicolumn{1}{c}{ A shift from } & \multicolumn{1}{c}{ A shift to } \\
1 & $\begin{array}{l}\text { Passive recipient of informa- } \\
\text { tion }\end{array}$ & $\begin{array}{l}\text { Active participant in the learn- } \\
\text { ing process }\end{array}$ \\
2 & Reproducing knowledge & $\begin{array}{l}\text { Producing and sharing knowl- } \\
\text { edge }\end{array}$ \\
3 & Learning as a solitary activity & $\begin{array}{l}\text { Learning collaboratively with oth- } \\
\text { ers }\end{array}$ \\
\hline
\end{tabular}

\section{LIMITATIONS OF MICROTEACHING}

- It is skill oriented; content not emphasized

- A large number of trainee teachers cannot be given the opportunity for re-teaching and re-planning

- It is very time consuming technique

- It requires special class room setting

- It covers only a few specific skills

- It deviates from normal class room teaching

- It may raise administrative problem while arranging micro-lessons

\section{MICROTEACHING Vs TRADITIONAL TEACHING}

Table 4: Comparison between microteaching and traditional teaching

\begin{tabular}{|c|c|c|}
\hline & Microteaching & Traditional teaching \\
\hline 1 & $\begin{array}{l}\text { Objectives are specified in be- } \\
\text { havioral terms }\end{array}$ & $\begin{array}{l}\text { Objectives are general and not } \\
\text { specified in behavioral terms }\end{array}$ \\
\hline 2 & $\begin{array}{l}\text { Class consists of small group } \\
\text { of } 5 \text { - } 10 \text { students }\end{array}$ & Class consists $40-60$ students \\
\hline 3 & $\begin{array}{l}\text { The teacher takes up one skill } \\
\text { at a time }\end{array}$ & $\begin{array}{l}\text { The teacher practices several } \\
\text { skills at a time }\end{array}$ \\
\hline 4 & $\begin{array}{l}\text { Duration time for teaching is } \\
5-10 \text { minutes }\end{array}$ & $\begin{array}{l}\text { Duration time for teaching is } 40 \\
-50 \text { minutes }\end{array}$ \\
\hline 5 & There is immediate feedback & $\begin{array}{l}\text { Immediate feedback is not avail- } \\
\text { able }\end{array}$ \\
\hline 6 & $\begin{array}{l}\text { Teaching is carried on under } \\
\text { controlled situation }\end{array}$ & There is no control over situation \\
\hline 7 & Teaching is relatively simple & Teaching become complex \\
\hline 8 & $\begin{array}{l}\text { The role of supervisor is spe- } \\
\text { cific and well defined to im- } \\
\text { prove teaching }\end{array}$ & $\begin{array}{l}\text { The role of the supervisor is } \\
\text { vague }\end{array}$ \\
\hline 9 & $\begin{array}{l}\text { Patterns of class room inter- } \\
\text { action can be studied objec- } \\
\text { tively }\end{array}$ & $\begin{array}{l}\text { Patterns of class room interac- } \\
\text { tions cannot be studied objec- } \\
\text { tively }\end{array}$ \\
\hline 10 & Provision for re-teaching & No \\
\hline 11 & $\begin{array}{l}\text { Trainee teachers gain confi- } \\
\text { dence in teaching }\end{array}$ & Tense and scared \\
\hline
\end{tabular}




\section{LINK PRACTICE (INTEGRATION OF TEACHING SKILLS)}

Link practice involves the integration of skills. The main objectives of integration of teaching skills are to help in the transition from microteaching situation to real teaching situation where the trainee teacher is allowed to teach all the skills together learnt in microteaching sessions.

The link practice may be defined as a process of selection, organization and utilization of different teaching skills to form an effective pattern for realizing the specified instructional objectives in a given teaching learning situation $^{18}$.

\section{CONCLUSIONS}

Microteaching is a teacher training concept that can be applied at the pre-service and in-service stages in the professional development of the teachers. Medical teachers have no special prior or in-service training in teaching. Microteaching helps medical teachers to improve their self-confidence and teaching skills. Microteaching is a vehicle of continuous training applicable at all stages not only to teachers at the beginning of their career but also for more senior teachers. Microteaching is an excellent way to build up skills and confidence, to experience a range of lecturing/tutoring styles and to learn and practice giving constructive feedback. Microteaching is a system of controlled practice that makes it possible to focus on specific teaching behaviors and to practice teaching under controlled conditions. Competence in one skill is developed before proceeding to another skill. Many institutions are using the microteaching model to raise the level of the teachers' competencies to develop teaching skills.

\section{Recommendations}

The Department of Medical Education should organize more microteaching sessions because microteaching experiences have a positive impact on teaching competencies.

\section{REFERENCES}

1. Elliot J. A microteaching experiment at MEDUNSA. S Afr Med J. 1982; 62: 868-70.

2. Singh LC, Sharma RD. Department of Teacher education NCERT, New Delhi. Microteaching -
Theory and practice. 1987.

3. Paintal I. Microteaching - A handbook for Teachers. Oxford University Press, New Delhi.1980.

4. Ananthakrishnan N. Microteaching as a vehicle of teacher training - Its advantages and disadvantages. J Postgrad Med. 1993; 39: 142-3.

5. Allen DW, Eve AW. Microteaching. Theory into Practice. 1968; 7(5):181-185.

6. Demir S. Two inseparable facets of technology integration programs: Technology and theoretical framework. Eurasia Journal of Mathematics, Science \& Technology Education. 2011; 7(2): 75-88.

7. Politzer R. Microteaching: A new approach to teacher training and research. Hispania. 1969; 52(2): 244-248.

8. Aggarwal JC. Essentials of Education Technology. Third edition, 2011.

9. Clift JC, Batten H, Burke G, Malley J. Structure of the skill acquisition phase of a microteaching.

10. Deighton LC (Ed). The Encyclopedia of Education. 1971; Vol 9.

11. Koross R. Microteaching an efficient technique for learning effective teaching skills: Pre-service teachers' perspective. IRA-International Journal of Education and Multidiciplinary Studies. 2016; 4(2): 289-299. 